\title{
Two-step freezing of two-cell rabbit embryos after partial dehydration at room temperature
}

\author{
J.-P. Renard*, Bui-Xuan-Nguyen $\dagger$ and V. Garnier \\ I.N.R.A., Station centrale de Physiologie animale, 78350 Jouy-en-Josas, France
}

\begin{abstract}
Summary. The effect of rapid freezing and thawing on the survival of 2-cell rabbit embryos was examined. When embryos in $2.2 \mathrm{M}$-propanediol were directly plunged from room temperature to liquid nitrogen some of them survived after thawing $(8 \%)$ but only if they had been pretreated by exposure to an impermeable solute, sucrose, that makes the blastomeres shrink osmotically before cooling. High survival $(77-88 \%)$ in vitro was obtained when pretreated embryos were first held at $-30^{\circ} \mathrm{C}$ for $30-240 \mathrm{~min}$ before immersion into liquid nitrogen. Transfer of such frozen-thawed embryos gave a survival rate to live young similar to that obtained with controls $(26 \%$ and $32 \%$ respectively). DMSO was less effective than propanediol; only 2 out of 38 sucrosepretreated frozen-thawed embryos developed in vitro.

The present work shows that a combination of partial dehydration of blastomeres at room temperature with their permeation by a cryoprotective agent offers a simple method for successful rapid freezing and thawing of rabbit embryos.
\end{abstract}

\section{Introduction}

Movement of water across the cell membrane and intracellular ice formation during cooling associated with crystal growth during warming are the major factors that affect the viability of frozen-thawed living systems (Mazur, 1963, 1977). Even for cells such as fibroblasts (Farrant, Walter, Heather \& McGann, 1977), skin cells (Sherman, 1962) or embryos (Willadsen, Polge, Rowson \& Moor, 1976; Whittingham, Wood, Farrant, Lee \& Hasley, 1979; Rall, Reid \& Farrant, 1980), which tolerate the presence of some intracellular ice well, water must be removed, at least partly, to prevent excess formation of ice during cooling or warming.

Dehydration is generally achieved during cooling to subzero temperatures in the presence of extracellular ice. Since the chemical potential of the intracellular water is higher than both that of the water and that of the ice in the extracellular medium, water tends to flow from the cells and freeze outside the cells (Mazur, 1963), which progressively shrink as the temperature is lowered (Diller, Cravalho \& Huggins, 1972; McGrath, Cravalho \& Huggins, 1975; Leibo, McGrath \& Cravalho, 1978).

Dehydration before cooling to subzero temperature by osmotic shrinkage of the cells is thought to be detrimental to their survival after freezing and thawing. Most cell types rapidly reach a minimum volume which impairs their further development (Meryman \& Hornblower, 1972; Farrant \& Woolgar, 1972). The removal of water increases the internal concentration of solutes, producing "solution effects" (Lovelock, 1953), which reduces the viability of the cells and becomes

\footnotetext{
* Present address: Institut Pasteur, Unité de Génétique des Mammifères, 25 rue du Docteur Roux, 75015 Paris, France.

† Present address: Laboratory of Biology of Reproduction, National Institute of Scientific Research, Hanoi, Vietnam.
} 
more damaging when the cells are cooled slowly (Morris \& Farrant, 1973). However, dehydration before cooling has been shown to be compatible with the viability of several frozen-thawed cell types, e.g. skin cells which have been partly dried in air before freezing (Taylor \& Gerstner, 1954) or red blood cells shrunken after exposure at room temperature to hyperosmotic solution containing sucrose, which is a non-permeable solute (Mazur, Miller \& Leibo, 1974). When combined with the protective effects offered by a permeating compound such as glycerol or dimethylsulphoxide (DMSO), dehydration before freezing can also increase the survival of fibroblasts (AshwoodSmith, 1975) or mouse embryos (Smorag, Katska \& Wierzbowski, 1981a; Massip \& Van der Zwalmen, 1982).

The viability of embryos is not affected when they are kept shrunken at room temperature for up to $30 \mathrm{~min}$ in solutions of PBS made hyperosmotic with sucrose (Renard, Heyman \& Ozil, 1982) or in association with a permeable cryoprotective agent such as propanediol (Bui-Xuan-Nguyen, Renard \& Garnier, 1983). The present paper investigates the effects of this treatment at room temperature on 2-cell rabbit embryos.

\section{Materials and Methods}

Two-cell rabbit embryos were recovered in PBS (Whittingham, 1971) supplemented with $20 \%$ fetal calf serum (FCS) at 26-28 h post coitum from 6-month-old virgin New Zealand White rabbits induced to superovulate with FSH and LH as described by Kennelly \& Foote (1965). The embryos were washed in 2 changes of medium and kept for up to $20 \mathrm{~min}$ at room temperature before use.

Eggs first were placed in a solution of PBS containing 1.5 M-1,2-propanediol or 1.5 M-DMSO for $30 \mathrm{~min}$ at room temperature. They then were incubated for 3-15 $\mathrm{min}$ at room temperature in solutions containing $2.2 \mathrm{M}$-propanediol $(16.7 \%, \mathrm{w} / \mathrm{v})$ or DMSO $(17 \cdot 2 \%$, w/v) in PBS $+20 \%$ FCS with or without sucrose $(0.5$ or $1.0 \mathrm{M})$. After this treatment eggs were directly placed back into 2 changes of PBS $+20 \%$ FCS and cultured in vitro for the assessment of their viability or they were rapidly frozen and thawed (see below). Variation in the size of the blastomeres before and after exposure to the solution containing both propanediol $(2.2 \mathrm{M})$ and sucrose $(0.5 \mathrm{M})$ was determined with an ocular micrometer: each blastomere was assumed to be a sphere whose diameter was defined as the square root of the product of length and width of the cell.

The freezing and thawing procedures used were derived from those described previously for the freezing of cattle blastocysts (Renard et al., 1982; Leibo, 1983) and 8-cell mouse embryos (Renard \& Babinet, 1984). Plastic straws $(500 \mu 1$; ref. UA 105, I.M.V., L’Aigle, France) were used as vessels for the freezing of the eggs. They were first filled by successive aspirations of the following fractions: Fraction A, $150 \mu \mathrm{l} \mathrm{0.05} \mathrm{M-sucrose} \mathrm{in} \mathrm{PBS} \mathrm{+} \mathrm{20 \%} \mathrm{FCS;} \mathrm{Fraction} \mathrm{B,} 40 \mu \mathrm{l}$ air ; Fraction C, $150 \mu 10.5$ M-sucrose in PBS; Fraction D, $20 \mu \mathrm{l}$ air; Fraction E, $40 \mu \mathrm{l} 2.2 \mathrm{M}$-propanediol or DMSO $+0.5-1.0 \mathrm{M}$ sucrose in PBS $+20 \%$ FCS. The straws were prepared and stored in one freezer at $-30^{\circ} \mathrm{C}$ for several weeks before being used.

At the time of use straws were removed from the freezer and held between two fingers placed on Fraction E. This allowed Fraction $E$ to be warmed more rapidly (a few seconds) than the other fractions of the straw. As soon as Fraction $E$ (or a part of it) was thawed, 4-5 embryos pipetted into a small amount of medium containing $0.5 \mathrm{M}$-sucrose plus $2.2 \mathrm{M}$-propanediol or DMSO in PBS + $20 \%$ FCS (as described above), were gently inserted into Fraction E. The straw was rapidly stoppered with a small plastic bung and then deposited horizontally into the chamber of a commercial programmable liquid nitrogen vapour freezing machine (Minicool, Air Liquide, Paris), precooled to $-30^{\circ} \mathrm{C}$. Each straw was kept for 5-240 min at this temperature before being rapidly cooled in liquid nitrogen $\left(-196^{\circ} \mathrm{C}\right)$. Using this procedure mean rate of cooling between $+20^{\circ} \mathrm{C}$ and $-25^{\circ} \mathrm{C}$, as determined for replicate straws $(n=9)$ which contained the tip of a Copper/Constantin thermocouple (diam. 0.3 mm; Cables Maret, Paris, France) inserted in Fraction $\mathrm{E}$, was $12^{\circ} \mathrm{C} \pm 0.9^{\circ} \mathrm{C} / \mathrm{min}$. Rate of cooling between -30 and $-196^{\circ} \mathrm{C}$ (liquid nitrogen) 
was about $1000^{\circ} \mathrm{C} / \mathrm{min}$. In some cases the straws were plunged directly from room temperature into the liquid nitrogen vapour.

The straws were thawed rapidly (a few seconds) by removing them from liquid nitrogen and plunging them directly into a $37^{\circ} \mathrm{C}$ waterbath. During thawing straws were held vertically in the bath, and moved gently to make the small bubble of air (Fraction D) rise, allowing the mixing of Fractions $C$ and $E$ and thus providing dilution of the cryoprotectant. After $5 \mathrm{~min}$ at $37^{\circ} \mathrm{C}$ the straw was removed from the waterbath and the contents were expelled into a Petri dish. The eggs then were washed in 2 changes of PBS and one change of Medium B2 (Ménézo, 1976).

The survival of the eggs was assessed by their ability to develop to the morula or early blastocyst stage during $48-72 \mathrm{~h}$ of culture at $37^{\circ} \mathrm{C}$ in Medium B2 in vitro or by their ability to develop into fetuses after transfer to the oviducts of pseudopregnant females. Transfers of eggs were done surgically (Staples, 1971) and each recipient received 8-10 embryos 18-22 h after their mating with a proven vasectomized male. The animals were examined at surgery 11 days after egg transfers and the numbers of implantation sites in each uterine horn were counted. Pregnant recipients were killed on Day 28 of gestation to determine the number of living young.

Significant differences and homogeneity between samples were determined using Student's $t$ test for differences of paired measurements of cell volume (before and after shrinkage with sucrose) and the $\chi^{2}$ test with Yates' correction for proportions.

\section{Results}

In a preliminary study two-cell rabbit embryos were placed progressively (stepwise addition) or directly into a solution of $2 \cdot 2 \mathrm{M}$-propanediol in PBS $+20 \% \mathrm{FCS}$ at room temperature for $30 \mathrm{~min}$. Stepwise addition consisted of first exposing the embryos to $0.5 \mathrm{M}$-propanediol during $5 \mathrm{~min}$ followed by a second exposure to $1.5 \mathrm{M}$-propanediol for $5 \mathrm{~min}$ before placing the embryos in $2.2 \mathrm{M}$ propanediol. After 30 min of treatment the embryos were placed directly in PBS $+20 \%$ FCS for 10 min and then they were cultured at $37^{\circ} \mathrm{C}$ in Medium B2 for up to $72 \mathrm{~h}$. Seventeen out of $20(85 \%)$ and 20 out of $22(90.9 \%)$ direct and stepwise embryos, respectively, developed to the morula stage. It therefore was concluded that the embryos could be exposed directly to $2 \cdot 2 \mathrm{M}$-propanediol at room temperature and equilibrated during $30 \mathrm{~min}$ without a marked effect on their subsequent viability.

In the first experiment, the embryos first were placed in $1.5 \mathrm{M}$-propanediol and exposed for up to $15 \mathrm{~min}$ at room temperature to a solution containing both propanediol $(2 \cdot 2 \mathrm{M})$ and sucrose $(0.5 \mathrm{or}$ $1.0 \mathrm{M}$ ). Exposure to the solution containing $0.5 \mathrm{M}$-sucrose for up to $15 \mathrm{~min}$ did not affect the survival of embryos (Table 1). Percentages of morulae obtained after 3, 5 or 15 min of treatment were $95.4 \%$ $(n=22), 100 \%(n=14)$ and $86.6 \%(n=30)$, respectively. These values were similar to those obtained with untreated embryos $(86.6 \%$ and $100 \%)$ after 5 and $15 \mathrm{~min}$ respectively in solutions

Table 1. Viability (\%) of unfrozen 2-cell rabbit embryos after partial dehydration at room temperature*

\begin{tabular}{ccrr}
\hline \multirow{2}{*}{$\begin{array}{c}\text { Sucrose conc. } \\
\text { in the suspending } \\
\text { medium (M) }\end{array}$} & $3 \mathrm{~min}$ & $5 \mathrm{~min}$ & $15 \mathrm{~min}$ \\
\cline { 2 - 4 } & & $86.6(2,15)$ & $100 \cdot 0(3,25)$ \\
0 & & \multicolumn{3}{c}{ Time } \\
0.5 & $95.4(3,22)$ & $100 \cdot 0(2,14)$ & $86.6(4,30)$ \\
1.0 & $77 \cdot 7(1,18)$ & $33.3(2,14)$ & $56.6(4,30)$ \\
\hline
\end{tabular}

* All embryos were equilibrated in PBS + 20\% FCS containing $2 \cdot 2 \mathrm{M}$-propanediol, which also was present at the same concentration in the suspending medium.

Values in parentheses represent the no. of trials and the total no. of embryos used. 
without sucrose. Increasing the concentration of sucrose to $1.0 \mathrm{M}$ tended to affect the development of embryos: $77.7 \%(n=18)$ developed normally after $3 \mathrm{~min}$, but only $33 \cdot 3 \%(n=24)$ and $56 \cdot 6 \%$ $(n=30)$ did so after 5 and 15 min of treatment, respectively. Although these were not significantly different from the controls we concluded that exposure to $0.5 \mathrm{M}$-sucrose at room temperature for up to 5 min was the optimal procedure compatible with a high survival rate of the embryos.

During this treatment embryos shrank markedly and remained shrunken as long as sucrose was present in the suspending medium. The zona pellucida was only slightly deformed and regained its spherical shape within the first 2 min of treatment. Maximum contraction of the cells was attained within 3-5 min; mean diameter of the blastomeres was reduced significantly $(P \leqslant 0.005)$ from 76.73 $\pm 1.20 \mu \mathrm{m}$ to $62.41 \pm 1.15 \mu \mathrm{m}(n=20)$. Assuming a spherical shape for the blastomeres, this represented a reduction of $46.1 \%$ in cell volume. When blastomeres were replaced in a solution of PBS containing $0.5 \mathrm{M}$-sucrose, but no propanediol, for $10 \mathrm{~min}$, the size of the cells was modified only slightly. Further dilution of sucrose resulted in a quick expansion of the blastomeres, which regained their original size within $5 \mathrm{~min}$ after having been placed in PBS $+20 \%$ FCS.

As shown in Table 2, when the embryos in $2.2 \mathrm{M}$-propanediol were taken from room temperature and plunged directly into liquid nitrogen without pretreatment with sucrose before freezing, none survived after rapid warming and dilution of the cryoprotectant. Most exhibited visible alteration of one or 2 blastomeres within a few min after thawing. When pretreated with $0.5 \mathrm{M}$-sucrose some of them ( 4 out of $48,8.3 \%$ ) underwent normal development to the morula stage. When rapid cooling from room temperature was interrupted at $-30^{\circ} \mathrm{C} 30-240$ min before plunging directly into liquid nitrogen, a high survival rate was obtained, but only for embryos that had been pretreated with sucrose. Without pretreatment with sucrose no thawed embryos survived when held for $30 \mathrm{~min}$ at $-30^{\circ} \mathrm{C}$ and only 3 developed to the 8-cell stage when kept for $240 \mathrm{~min}$ at this temperature before freezing in liquid nitrogen.

From the 88 pretreated embryos held for at least $30 \mathrm{~min}$ or longer at $-30^{\circ} \mathrm{C}$ before plunging them into liquid nitrogen, $75 \%(66 / 88)$ had 2 blastomeres apparently intact after thawing, whereas $17.0 \%(15 / 88)$ had one damaged blastomere and only $8 \%(7 / 88)$ were completely disorganized.

To compare the protective effects of propanediol and DMSO on 2-cell rabbit embryos, embryos were exposed to $1.5 \mathrm{M}$-propanediol, pretreated with $2.2 \mathrm{M}$-propanediol or DMSO $+0.5 \mathrm{M}$-sucrose for $5 \mathrm{~min}$ at room temperature, directly cooled to $-30^{\circ} \mathrm{C}$ with $30 \mathrm{~min}$ of holding time before being plunged into liquid nitrogen, and rapidly thawed in a waterbath at $20^{\circ} \mathrm{C}$. After thawing, the percentage of embryos that looked morphologically normal tended to be less when embryos had been frozen in $2.2 \mathrm{M}$-DMSO than when embryos had been frozen with the same concentration of propanediol (Table 3). The overall survival rate with DMSO was less than that obtained with propanediol.

The results after transfer of embryos to pseudopregnant females are given in Table 4. Values for frozen embryos were not significantly different from those obtained for unfrozen embryos.

Table 2. Viability in vitro of 2-cell rabbit embryos after two-step freezing and rapid rewarming in the presence of $2 \cdot 2 \mathrm{M}$-propanediol

\begin{tabular}{|c|c|c|c|c|c|}
\hline \multirow{3}{*}{$\begin{array}{l}\text { Holding time } \\
\text { at }-30^{\circ} \mathrm{C} \\
(\mathrm{min})\end{array}$} & \multirow{2}{*}{\multicolumn{2}{|c|}{$\begin{array}{l}\begin{array}{l}\text { Pretreatment at room temperature } \\
\text { in } 0.5 \mathrm{M} \text {-sucrose }\end{array} \\
\text { No. of embryos }\end{array}$}} & \multirow{2}{*}{\multicolumn{3}{|c|}{$\begin{array}{l}\text { No pretreatment } \\
\text { No. of embryos }\end{array}$}} \\
\hline & & & & & \\
\hline & \multicolumn{2}{|r|}{ Developing to morulae } & Frozen & \multicolumn{2}{|c|}{ Developing to morula } \\
\hline 0 & 48 & $4(8 \cdot 3 \%)$ & 30 & 0 & \\
\hline 5 & 20 & 0 & - & - & - \\
\hline 15 & 30 & $10(33 \cdot 3 \%)$ & 22 & 0 & - \\
\hline 30 & 35 & $29(82.8 \%)$ & 23 & 0 & - \\
\hline 150 & 31 & $26(83.8 \%)$ & 19 & $2(1$ & $0.5 \%$ \\
\hline 240 & 22 & $17(77 \cdot 2 \%)$ & 21 & $3(1$ & $4.2 \%$ \\
\hline
\end{tabular}


Table 3. Protective effects of propanediol and DMSO on 2-cell rabbit embryos partly dehydrated at room temperature before 2-step freezing and rapid thawing

\begin{tabular}{llcc}
\hline & \multicolumn{3}{c}{ Cryoprotectant* } \\
\cline { 2 - 4 } & Propanediol & DMSO & $\begin{array}{c}\text { None } \\
\text { (sucrose only) }\end{array}$ \\
\hline $\begin{array}{l}\text { No. of embryos frozen } \\
\text { No. of normal embryos after } \\
\text { thawing }\end{array}$ & 54 & 38 & 25 \\
$\begin{array}{l}\text { No. of embryos developing } \\
\text { To 8-cell stage } \\
\text { To morula }\end{array}$ & $51(94 \cdot 4 \%)$ & $29(76 \cdot 3 \%)$ & $19(76.0 \%)$ \\
\hline $\begin{array}{l}\text { No. of unfrozen (control) embryos } \\
\text { Treated }\end{array}$ & $50(92 \cdot 5 \%)$ & $8(21.0 \%)$ & 0 \\
Developing to morula & $48(88.8 \%)$ & $2(5 \cdot 3 \%)$ & 0 \\
\hline
\end{tabular}

* Each cryoprotectant was used at a final concentration of $2 \cdot 2 \mathrm{M}$.

Table 4. Development in vivo of 2-cell rabbit embryos partly dehydrated at room temperature before 2-step freezing and rapid warming

\begin{tabular}{lcc}
\hline & $\begin{array}{c}\text { Frozen } \\
\text { embryos* }\end{array}$ & $\begin{array}{c}\text { Unfrozen } \\
\text { (control) }\end{array}$ \\
\hline No. of recipients & & \\
$\quad$ Receiving transfers & 10 & 6 \\
$\quad$ Pregnant at Day 12 & 8 & 5 \\
No. of embryos transferred & 90 & 59 \\
$\quad$ Total & 71 & 49 \\
$\quad$ In pregnant recipients & 27 & 21 \\
No. of fetuses at Day 12 & $21 \dagger$ & 19 \\
No. of live young at Day 28 & & \\
Survival rate at Day 28 & $25.9 \% \dagger$ & $32.2 \%$ \\
$\quad$ Total & $33.8 \% \dagger$ & $38.7 \%$ \\
$\quad$ For pregnant recipients &
\end{tabular}

* Embryos were frozen in the presence of $2.2 \mathrm{M}$ propanediol and $0.5 \mathrm{M}$-sucrose (see text).

$\dagger$ Excluding one recipient which received 9 embryos but died at Day 14 with 3 fetuses.

\section{Discussion}

The present work shows that partial dehydration of 2-cell rabbit embryos for up to 15 min at room temperature did not affect their subsequent viability and that this treatment permitted a high survival rate after rapid freezing and thawing.

In these studies the cell volume of the embryos was reduced to about $50 \%$ of the original volume by exposure to $0.5 \mathrm{M}$-sucrose. Several mammalian cells in culture tolerate a similar osmotic shrinkage (Meryman, 1974; Micronescu, 1977) and their metabolic activity is not reduced even when the cell ultrastructure appears markedly altered by shrinkage (Mansell \& Clegg, 1983). In previous work we showed that cattle blastocysts survived exposure to $1.0 \mathrm{M}$-sucrose for $30 \mathrm{~min}$ at $37^{\circ} \mathrm{C}$ (Renard et al., 1982) and Kasai, Niwa \& Iritani (1983) obtained normal development of mouse and rat morulae kept shrunken for 5 days at $0^{\circ} \mathrm{C}$ in $0.75 \mathrm{M}$-sucrose. It therefore appears that even a greater degree and longer period of dehydration than that used in the present study might not be harmful when embryos are kept at room temperature. 
Our work shows that partial shrinkage of the blastomeres before cooling confers some protection against injuries resulting from rapid freezing and thawing; some embryos may survive even after plunging them directly into liquid nitrogen. However, a holding time of at least $30 \mathrm{~min}$ at $-30^{\circ} \mathrm{C}$ appears to be necessary to achieve a high survival rate $(>85 \%$ in vitro $)$. The beneficial effect of an equilibration period at subzero temperature has been observed previously with rapidly frozen mouse embryos (Wood \& Farrant, 1980; Smorag, Katska \& Wierzchos, 1981b). We consider that during the holding period at $-30^{\circ} \mathrm{C}$ the osmotic shrinkage of the embryos completes the initial shrinkage obtained with sucrose at room temperature. However, when the embryos are shrunken more severely by short exposure to 1.0 or $1.5 \mathrm{M}$-sucrose before cooling none of them survive after being plunged directly into liquid nitrogen and the blastomeres were often found to be damaged just after thawing (unpublished observations). It must therefore be considered that the beneficial effect of the equilibration period is dependent not only on the further reduction of cell volume but must also be related to other causes. At fast cooling rates cell volume changes are not a function of the relative initial cell size: heat transport dominates the mass transport creating a large osmotic disequilibrium on membranes (Schwartz \& Diller, 1983). Reduction of this transient effect imposed on cell membranes during rapid cooling could explain the beneficial consequences of the holding time at subzero temperature.

Survival of frozen-thawed 2-cell stage rabbit embryos can be obtained only when a permeable cryoprotectant is added to the suspending medium. Exposure to solutions containing only sucrose afford no protection. This clearly indicates that more than simple dehydration is involved in the protection of cells during cooling and thawing. However, DMSO offers limited protection to the embryos: $70 \%$ of them looked normal after thawing but only $5 \%$ developed in vitro. In contrast, propanediol is effective, since almost all of the embryos apparently were intact after thawing and developed in vitro. The difference between the survival of embryos frozen and thawed in propanediol or DMSO is presumably due to the formation of a lethal quantity of intracellular ice in the latter but not the former. It is known that during rapid cooling large fractions of solution remain unfrozen and the crystalline and amorphous phases are closely intermingled (Luyet, 1970). From $-40^{\circ} \mathrm{C}$ down to the temperature of liquid nitrogen no ice will form in embryos that are cooled rapidly (Rall et al., 1980; Rall, Reid \& Polge, 1984), and so ice crystals must be formed at higher subzero temperatures. From scanning differential calorimetry studies of a solution of PBS $+20 \%$ FCS supplemented with 1.0-3.0 M-propanediol or DMSO, we estimated that about $10-15 \%$ more ice crystallizes during cooling at $20^{\circ} \mathrm{C} / \mathrm{min}$ with DMSO than with propanediol (J.-P. Renard \& P. Boutron, unpublished data). Additional comparisons of the phase diagrams of the binary system water-DMSO (Rasmussen \& MacKenzie, 1968) and water-propanediol (Boutron \& Kaufmann, 1979 ) indicates that during rapid cooling the amorphous state can be obtained more easily with propanediol than with DMSO. Crystallization on quenching is prevented with a solution containing only $35 \%$ propanediol (by wt); whereas a concentration of more than $45 \%$ DMSO (by $\mathrm{wt}$ ) is necessary to get the same results. These data could to some extent explain the difference in cryoprotective effect between DMSO and propanediol.

In our study nearly $90 \%$ of the embryos developed after rapid freezing and thawing. This percentage is higher than that obtained in previous studies with embryos frozen at the same stage of development ( $30 \%$ of normal eggs after thawing; Tsunoda, Shimohora, Izumi, Soma \& Sugie, 1979) but comparable to the $80 \%$ survival rate obtained when rabbit embryos are frozen at later stages from 8 cells to blastocysts (Maurer \& Haseman, 1976; Whittingham \& Adams, 1976; Tsunoda \& Sugie, 1977; Landa, 1982a). Almost no embryos exhibited damaged zonae or mucin coats after thawing. As discussed by Landa (1982b), this may be due to the rapid melting of extracellular ice produced by the high rate of thawing we used and which is favoured by the large surface area and relatively small amount of medium frozen in plastic straws. Beneficial effects resulting from use of this type of container have been observed with mouse 8-cell embryos (Renard \& Babinet, 1984). This may be related to the absence of 'fracture lines' which can be observed under the cryomicroscope in the ice matrix of rapidly cooled preparations (Rall et al., 1984). The two 
blastomeres of rabbit embryos are often of unequal size (Assheton, 1894) but their behaviour during freezing and thawing is similar.

In the present work few embryos frozen under optimal conditions (with propanediol) exhibited one damaged blastomere. Human embryos at the 2-cell stage have an average blastomere diameter only slightly less than that of the rabbit (50-75 $\mu \mathrm{m}$; Dvorak, Tesarik, Pilka \& Travnik, 1982; $76 \mu \mathrm{m}$ in the present work); unequal distribution of size within one given embryo also is frequently observed (J. Testart, personal communication); these considerations make the rabbit useful for studies on the freezing of human embryos.

Two additional aspects of this study must be considered regarding their possible application to the practical banking of rabbit embryos. Firstly, the present procedure allows several simplifications of the technique of freezing: the straws we used can be prepared in advance and kept frozen; no manual seeding of the extracellular medium is necessary during rapid cooling to $-30^{\circ} \mathrm{C}$; this temperature corresponds to that of ordinary freezers and the embryos can be kept there for various periods of time (30-240 $\mathrm{min}$ ) before their storage in liquid nitrogen; and dilution of propanediol after thawing is achieved directly inside the straws. Secondly, the stage of development used is compatible with multiple non-surgical recovery of embryos from a given donor: the actual limit of repeated treatments on the same female is not so much the sensitivity of the ovaries to multiple stimulation with gonadotrophins but the consequences of several surgical operations commonly used for recovery (Maurer, Hunt \& Foote, 1968); egg recovery from flushings of the vagina of females treated with prostaglandin F- $2 \alpha$ offers an attractive possibility for nonsurgical recovery in the rabbit (Takeda, Suzuki, Terami \& Tsutsumi, 1979). This procedure leads to an acceptable recovery rate $(45-90 \%)$ providing embryos are collected as early as $22-27 \mathrm{~h}$ after mating. This corresponds to the stage of development used in our study.

We thank Dr Z. Smorag for critical and valuable reading of the manuscript.

\section{References}

Ashwood-Smith, M.J. (1975) Current concepts concerning radioprotective and cryoprotective properties of dimethylsulfoxide in cellular systems. Ann. N.Y. Acad. Sci. 243, 246-256.

Assheton, M.A. (1894) A re-investigation into the early stages of the development of the rabbit. $Q$. Jl Microsc. 37, 113-163.

Boutron, P. \& Kaufmann, A. (1979) Stability of the amorphous state in the system water-1,2-propanediol. Cryobiology 16, 557-568.

Bui-Xuan-Nguyen, Renard, J.-P. \& Garnier, V. (1983) Rapid freezing and thawing of 2 cell stage rabbit embryos after partial dehydration at room temperature. Cryobiology 20, 742, Abstr.

Diller, K.R., Cravalho, E.G. \& Huggins, C.E. (1972) Intracellular freezing in biomaterials. Cryobiology 9 , $429-440$.

Dvorak, M., Tesarik, J., Pilka, L. \& Travnik, P. (1982) Fine structure of human two-cell ova fertilized and cleaved in vitro. Fert. Steril. 37, 661-667.

Farrant, J. \& Woolgar, A.E. (1972) Human red cells under hypertonic conditions; a model system for investigating freezing damage. Cryobiology 9, 9-21.

Farrant, J., Walter, C.A., Heather, L.E.E. \& McGann, L.E. (1977) Use of two-step cooling procedures to examine factors influencing cell survival following freezing and thawing. Cryobiology 14, 273-286.

Kasai, M., Niwa, K. \& Iritani, A. (1983) Protective effect of sucrose on the survival of mouse and rat embryos stored at $0^{\circ} \mathrm{C}$. J. Reprod. Fert. 68, 377-380.

Kennelly, J.J. \& Foote, R.H. (1965) Superovulatory response of pre- and post-pubertal rabbits to commercially available gonadotrophins. J. Reprod. Fert. 9 , 177-188.

Landa, V. (1982a) Rapid thawing of rabbit embryos after storage at $-196^{\circ} \mathrm{C}$. Folia biol., Praha $28,67-73$.

Landa, V. (1982b) Protection of non cellular investments of rabbit morulae stored at $-196^{\circ} \mathrm{C}$. Folia biol., Praha 28, 350-358.

Leibo, S.P. (1983) A one-step in situ dilution method for frozen-thawed bovine embryos. Cryo-letters 4, 387400.

Leibo, S.P., McGrath, J.J. \& Cravalho, E.G. (1978) Microscopic observation of intracellular ice formation in unfertilized mouse ova as a function of cooling rate. Cryobiology 15, 257-271.

Lovelock, J.E. (1953) The mechanism of the protective action of glycerol against haemolysis by freezing and thawing. Biochim. Biophys. Acta 11, 28-36.

Luyet, B.J. (1970) Physical changes occurring in frozen solutions during rewarming and melting. In The Frozen Cell, pp. 27-46. Eds G. E. W. Wolstenholme \& M. O'Connor. Churchill, London.

Mansell, J.L. \& Clegg, J.S. (1983) Cellular and molecular consequences of reduced cell water content. Cryobiology 20, 591-612. 
Massip, A. \& Van der Zwalmen, P. (1982) In vitro survival of mouse embryos frozen in glycerol or glycerolsucrose. Cryo-letters 3, 326, Abstr.

Maurer, R.R. \& Haseman, J.K. (1976) Freezing morula stage rabbit embryos. Biol. Reprod. 14, 256-263.

Maurer, R.R., Hunt, W.L. \& Foote, R.H. (1968) Repeated superovulation following administration of exogenous gonadotrophins in Dutch-Belted rabbits. J. Reprod. Fert. 15, 93-102.

Mazur, P. (1963) Kinetics of water loss from cells at subzero temperatures and the likelihood of intracellular freezing. J. gen. Physiol. 47, 357-369.

Mazur, P. (1977) The role of intracellular freezing in the death of cells cooled at superoptimal rates. Cryobiology 14, 251-272.

Mazur, P., Miller, R.H. \& Leibo, S.P. (1974) Survival of frozen-thawed bovine red cells as a function of the permeation of glycerol and sucrose. J. Membr. Biol. 15, 137-158.

McGrath, J.J., Cravalho, E.G. \& Huggins, C.E. (1975) An experimental comparison of intracellular ice formation and freeze-thaw survival of HeLa S-3 cells. Cryobiology 12, 540-550.

Ménézo, Y. (1976) Mise au point d'un milieu artificiel défini pour la survie et la maturation des gamètes et pour la culture de l'oeuf fécondé. $C$. r. hebd. Séanc. Acad. Sci., Paris, D 282, 1967-1970.

Meryman, H.T. (1974) Freezing injury and its prevention in living cells. Ann. Rev. Biophys. 3, 341-363.

Meryman, H.T. \& Hornblower, M. (1972) Changes in red cells following rapid freezing with extracellular cryoprotective agents. Cryobiology 9, 262-267.

Micronescu, S. (1977) Hyperosmotic injury in mammalian cells. 1. Survival of CHO cells in unprotected and DMSO-treated culture. Cryobiology 14, 451-465.

Morris, G.J. \& Farrant, J. (1973) Effects of cooling rate on thermal shock hemolysis. Cryobiology 10, 119-125.

Rall, W.F., Reid, D.S. \& Farrant, J.V. (1980) Innocuous biological freezing during warming. Nature, Lond. 286, 511-514.

Rall, W.F., Reid, D.S. \& Polge, C. (1984) Analysis of slow warming injury of mouse embryos by cryomicroscopical and physicochemical methods. Cryobiology 21, 106-121.

Rasmussen, D.H. \& Mackenzie, A.P. (1968) Phase diagram for the system water-dimethylsulphoxide. Nature, Lond. 220, 1315-1317.

Renard, J.-P. \& Babinet, C. (1984) High survival of mouse embryos after rapid freezing and thawing inside plastic straws with 1,2-propanediol as cryoprotectant. J. exp. Zool. 230, (in press).

Renard, J.-P., Heyman, Y. \& Ozil, J.P. (1982) Congélation de l'embryon bovin: une nouvelle méthode de décongélation pour le transfert cervical d'embryons conditionnés une seule fois en paillettes. Annls Méd. vét. 126, 23-32.

Schwartz, G.J. \& Diller, K. (1983) Osmotic response of individual cells during freezing. Cryobiology 20, 6177.

Sherman, J.K. (1962) Survival of higher animal cells after the formation and dissolution of intracellular ice. Anat. Rec. 144, 171-189.

Smorag, Z., Katska, L. \& Wierzbowski, S. (1981a) Some factors affecting the success of embryo freezing: storage before freezing, superovulation rate, PBS concentration, cooling and thawing rates. In Frozen Storage of Laboratory Animals, pp. 45-54. Ed. G. H. Zeilmaker. Gustav Fischer, Stuttgart.

Smorag, Z., Katska, L. \& Wierzchos, E. (1981b) Some factors affecting the viability of mouse and cattle embryos frozen to $-40^{\circ} \mathrm{C}$ before transfer in liquid nitrogen. Anim. Reprod. Sci. 4, 65-72.

Staples, R.E. (1971) Blastocyst transplantation in the rabbit. In Methods in Mammalian Embryology, pp. 290-304. Ed. J. C. Daniel, Jr. Freeman \& Co., San Antonio.

Takeda, T., Suzuki, H., Terami, Y. \& Tsutsumi, Y.T. (1979) Egg recovery from the vagina of the rabbit treated with prostaglandin F2. Japan. J. Anim. Reprod. 25, 23-30.

Taylor, A.C. \& Gerstner, R. (1954) Tissue survival after exposure to low temperatures and the effectiveness of protective pretreatments. J. cell. comp. Physiol. 46, 477-502.

Tsunoda, Y. \& Sugie, T. (1977) Effect of the freezing medium on the survival of rabbit eggs after deep freezing. J. Reprod. Fert. 50, 123-124.

Tsunoda, Y., Shimohora, Y., Izumi, K., Soma, T. \& Sugie, T. (1979) The survival of rabbit eggs stored in liquid nitrogen at different developing stages. Japan. J. Anim. Reprod. 25, 189-193.

Whittingham, D.G. (1971) Survival of mouse embryos after freezing and thawing. Nature, Lond. 233, 125126.

Whittingham, D.G. \& Adams, C.E. (1976) Low temperature preservation of rabbit embryos. J. Reprod. Fert. 47, 269-274.

Whittingham, D.G., Wood, M.J., Farrant, J., Lee, H. \& Halsey, J.D. (1979) Survival of frozen mouse embryos after rapid thawing from $-196^{\circ} \mathrm{C}$. J. Reprod. Fert. 56, 11-21.

Willadsen, S.M., Polge, C., Rowson, L.E.A. \& Moor, R.M. (1976) Deep freezing of sheep embryos. $J$. Reprod. Fert. 46, 151-154.

Wood, M.J. \& Farrant, J. (1980) Preservation of mouse embryos by two-step freezing. Cryobiology 17, 178180.

Received 5 December 1983 